\title{
Naturalismo e banalidade em Um canalha (1895), de Figueiredo Pimentel
}

\author{
Naturalism and banality in Um canalha (1895), by Figueiredo Pimentel
}

\author{
LEONARDO MENDES \\ RENATA FERREIRA VIEIRA \\ Universidade Federal do Rio de Janeiro (FAPERJ) - Rio de Janeiro - Rio de Janeiro - Brasil
}

a

\begin{abstract}
Resumo: O nome do escritor Alberto Figueiredo Pimentel (1869-1914) é uma ausência notável na história da literatura brasileira e, principalmente, na história do naturalismo no Brasil. O objetivo deste trabalho é estudar a trajetória do escritor e sua relação com a estética naturalista por meio do estudo de seu segundo romance: Um canalha, publicado pela Livraria Laemmert no Rio de Janeiro em 1895. Adotamos uma concepção ampliada de naturalismo como estética da civilização industrial do século XIX, destemida do paradoxo, capaz de acomodar subgêneros, apropriações, vertentes e modos de execução estranhos à historiografia tradicional, mas que eram reconhecidos como "naturalistas" no momento de sua primeira circulação. Ao estudar a obra do autor, chamamos a atenção para uma vertente pouco conhecida da estética, que o crítico David Baguley (1990) chamou de "naturalismo da desilusão", interessado em retratar o banal, o anti-heroico e o que "não acontecia" na vida dos personagens.
\end{abstract}

Palavras-chave: Alberto Figueiredo Pimentel; Naturalismo; Banalidade; Romance brasileiro

\begin{abstract}
Writer Alberto Figueiredo Pimentel (1869-1914) has been a notable absence in the history of Brazilian history and principally in the history of naturalism in Brazil. This works aims at studying the writer's trajectory and his relationship with naturalism, having as focus of interest his second novel: Um canalha, published by Livraria Laemmert in Rio de Janeiro in 1895. We adopt an expanded understanding of naturalism as the aesthetics of nineteenthcentury industrial civilization, unafraid of paradox, capable of accommodating subgenres and trends with which historiography is not familiar, but which were considered to be "naturalist" at the time the works were published. In studying the author's work, we highlight a less known strand of naturalism, that critic David Baguley calls "naturalism of disillusionment", which aims at portraying the banal, the anti-heroic and what "did not happen" in the character's lives.
\end{abstract}

Keywords: Alberto Figueiredo Pimentel; naturalism; banality; Brazilian novel

\section{I}

O nome do escritor Alberto Figueiredo Pimentel (1869-1914) é uma ausência notável na história da literatura brasileira e, principalmente, na história do naturalismo no Brasil. Atuante nos campos literário e jornalístico do Rio de Janeiro nos anos incipientes da República (1890-1910), praticante de vários gêneros textuais, do romance naturalista ao conto de fadas, Figueiredo Pimentel, entretanto, foi esquecido pelo grande público e seletivamente estudado pela historiografia. Conhecemos aspectos de sua trajetória como cronista da moda durante as reformas urbanas do Rio de Janeiro da década de 1900 (NEEDEL, 1993), assim como autor bem-sucedido de literatura infantojuvenil (LEÃO, 2012), mas sua história como escritor naturalista ainda aguarda para ser estudada.

Tendo como foco de interesse a história de publicação e recepção imediata do segundo romance do autor, $U m$ canalha, publicado no Rio de Janeiro pela Livraria Laemmert, em 1895, esse trabalho objetiva contribuir para essa nova historiografia do naturalismo no Brasil. Como se trata de um conhecimento novo, nossas fontes serão, além dos escritos do autor e de sua esparsa fortuna crítica, os periódicos em que trabalhou e nos quais se emitiram opiniões sobre ele e sua obra, disponíveis na Hemeroteca Digital Brasileira/FBN. Adotamos uma concepção ampliada de naturalismo como estética da civilização industrial do século XIX, destemida do paradoxo, capaz de acomodar subgêneros, apropriações, vertentes e 
modos de execução estranhos à historiografia tradicional (BAGULEY, 1990), mas que eram reconhecidos como "naturalistas" no momento de sua primeira circulação.

\section{II}

Alberto Figueiredo Pimentel nasceu em Macaé (RJ), mas foi em Niterói, a então capital da província, que iniciou a carreira de escritor no final da década de 1880 . Ingressou ainda jovem no jornalismo, assinando, com vários pseudônimos, crônicas e folhetins na imprensa local, com destaque para "Chico Botija", signatário da coluna "Entre as $\mathrm{X}$ e as XI" no jornal niteroiense Província do Rio. Foi nesse periódico que em 1889 ele publicou em folhetins o romance $O$ Artigo 200, com o pseudônimo de Albino Peixoto. Fazendo referência ao artigo do Código Penal do Império que criminalizava o aborto, a obra contava a história de Maricota, uma jovem de dezoito anos de modestas posses, natural de Rio Bonito (RJ) e moradora do bairro de Icaraí em Niterói. Maricota era uma moça avançada entre seu grupo de amigas, lia romances naturalistas franceses e sentia-se confortável com o próprio corpo e com a sexualidade. Ao final ela engravidava e morria ao tentar um aborto com a ajuda do primo, que era farmacêutico e pai da criança.

Supostamente verídico, o caso era narrado com uma franqueza inaudita no romance brasileiro. $\mathrm{O}$ folhetim causou tanto escândalo que o Província do Rio se viu obrigado a interromper a publicação antes do final da história. Houve cancelamentos de assinaturas e a redação foi inundada por cartas de reclamação. Só em 1893 Figueiredo Pimentel lograria publicar a obra completa em formato de livro, com o título sensacionalista de $O$ aborto, pela Livraria do Povo, do Rio de Janeiro. O romance fazia referências explícitas à urina, à menstruação e ao sexo, assim como reivindicava, tanto no prefácio quanto no corpo da obra, filiação ao naturalismo e ao romance de Emile Zola (1840-1902). Anunciado nos jornais como "romance naturalista" ou "romance realista" (a distinção não era obrigatória), a obra obteve sucesso imediato, com vendas de seis mil exemplares em alguns meses números impressionantes para a época (CATHARINA, 2013; EL FAR, 2004).

Para um romancista estreante, foi um começo promissor, que lhe trouxe fama e infâmia. Em dezembro de 1894, quando, numa nota sem assinatura, o influente jornal Gazeta de Notícias, do Rio de Janeiro, anunciou o lançamento do segundo romance de Figueiredo Pimentel, seu nome aparecia associado tanto ao naturalismo quanto à literatura infantojuvenil: "Laemmert \& C. compraram a propriedade de Um canalha, romance naturalista de Figueiredo Pimentel, autor de O aborto, Contos da Carochinha, Fototipias etc. A obra, excelentemente impressa, sairá dentro de pouco tempo" (Gazeta de Notícias, 19/12/1894, p.2). Aos olhos da Gazeta, Figueiredo Pimentel era um escritor novato que escrevia em vários gêneros, para vários públicos. Além dos sonetos de Fototipias para os amantes da poesia, havia uma prosa para adultos - o romance naturalista, muitas vezes confundido com o chamado "romance para homens" ou "romance de sensação" (EL FAR, 2004), e ainda uma literatura para crianças. A nota revelava que o sucesso de estreia do escritor lhe abrira as portas de editoras de maior prestígio, como a Laemmert, com distribuidores em São Paulo e no Recife, o que era crucial para a circulação das obras.

A Laemmert era uma das livrarias-editoras mais antigas da cidade (HALLEWELL, 1985). Especializada em livros técnicos e científicos, publicou por décadas o pioneiro Almanaque administrativo, mercantil e comercial do Rio de Janeiro, conhecido popularmente como Almanaque Laemmert. A partir de 1890, com a morte de Baptiste-Louis Garnier (1823-1893), proprietário da Livraria Garnier (que editava as obras de Machado de Assis e Aluísio Azevedo), a Laemmert começou a explorar o mercado de obras literárias, até então dominado pela editora rival. A publicação do romance naturalista de Figueiredo Pimentel era prova de que a Laemmert trabalhava para expandir seu público leitor e explorar o filão da leitura como entretenimento, em franca expansão no Rio de Janeiro na década de 1890 (EL FAR, 2004).

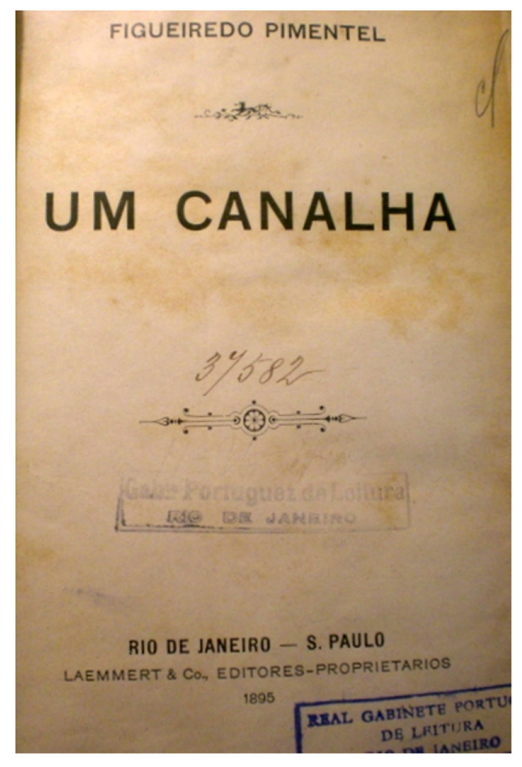

Fig. 1. Folha de rosto da primeira edição de Um canalha (1895), de Figueiredo Pimentel.

Exemplar do Real Gabinete Português de Leitura do Rio de Janeiro. ${ }^{1}$

\footnotetext{
Agradecemos à prof. Madalena Vaz-Pinto (RGPL/UERJ) por facilitar o acesso ao exemplar.
} 
O romance só apareceria em julho do ano seguinte, a três mil réis - preço médio de um livro de duzentas páginas. A Gazeta de Notícias anunciou a publicação em nota na primeira página na edição de 31 de julho de 1895: "O sr. Figueiredo Pimentel acaba de publicar um novo romance - Um canalha, elegantemente editado pela casa Laemmert. A obra do jovem escritor merece de certo crítica especial, a que não nos esquivaremos. Por hoje só nos cabe agradecer o mimo da oferta". Aparentemente a crítica da Gazeta ficou na promessa, pois o jornal se limitou a republicar no dia 19 de agosto uma nota saída originalmente num jornal paulista, já então reproduzida em $O$ país, do Rio, no dia 11 do mesmo mês:

Da antiga e conceituada casa Laemmert, da Capital Federal, com agência nesta cidade, à rua do Comércio, recebemos: Um canalha - chama-se assim o novo romance do conhecido literato Figueiredo Pimentel, o mesmo que, não há muito, publicou no Rio um livro em demasia realista e que, escrito em linguagem pouco literária, teve aqui e naquela (dizem-no, pelo menos, os respectivos cartazes), extraordinária extração meia dúzia de milhares de volumes. É grande, porém, a distância que separa o livro que temos em mãos daquele que tanto popularizou o talentoso escritor e original de Suicida. De fato, Um canalha, longe de ser um amontoado extravagante de fatos que em nada se recomendam pela moralidade, é um conjunto de quase duzentas páginas que se leem com agrado, sem nos fatigarem o espírito, tanto é leve e atraente a maneira por que se exprime o autor. Apesar de ressentir-se de algumas faltas, o romance do Sr. Figueiredo Pimentel apresenta-nos páginas de rara felicidade, e é com prazer que felicitamos o seu autor pela publicação desse livro, que, incontestavelmente bem superior a $O$ aborto, nos faz esperar ainda muito das qualidades que para esse gênero de literatura tem revelado o operoso literato (Gazeta de Notícias, 19/08/1895, p. 3). ${ }^{2}$

Embora superficial e enterrada na página 3, a nota era simpática a Um canalha, especialmente porque ele se afastava do naturalismo de escândalo, "demasiado realista", do romance de estreia. O desconforto do articulista com as audácias (e com a "linguagem pouco literária") de $O$ aborto foi sentimento comum entre os homens de letras. Artur Azevedo (1855-1908), em $O$ álbum, chegou a dizer que não leria o romance por se tratar de "um livro de escândalo". De sua posição de escritor dominante, Artur, o "papá literário" (como era conhecido), aconselhou: "Figueiredo Pimentel, faça outro livro, mas deixe-se de escândalos" ( $O$ álbum, n. 14, abril de 1893, p. 107). Com a publicação de Um canalha,

\footnotetext{
2 Embora a nota se refira a Figueiredo Pimentel como autor do romance Suicida, a obra não fora ainda publicada em formato de livro, tendo sido apenas divulgada em folhetins no jornal A noticia naquele ano. Por isso, Um canalha foi o segundo romance do autor publicado por uma livraria.
}

Figueiredo Pimentel aparentemente seguia os conselhos do escritor veterano: a obra era "incontestavelmente bem superior" a $O$ aborto. Até pelo menos 1898 a imprensa anunciou regularmente a disponibilidade do romance em livrarias da capital e das províncias.

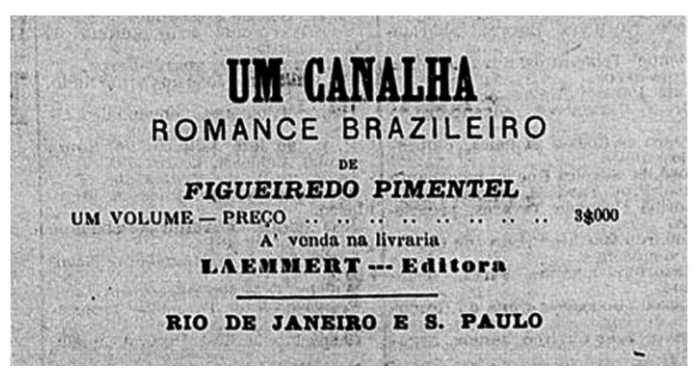

Fig. 2. Um canalha (romance brasileiro) à venda na Livraria Laemmert portrês mil réis. Fonte: Gazeta da Tarde, Rio de Janeiro, 17/08/1895, p. 4.

A obra acompanhava mais ou menos vinte anos da vida do bacharel mineiro Dr. Guarani Cardoso, desde os tempos de estudante na Faculdade de Direito de São Paulo (quando se chamava Manuel Antônio Cardoso), até seu suicídio numa delegacia em Niterói, aos quarenta e poucos anos, depois de uma carreira nada brilhante, marcada por calotes, traições e falcatruas. Sua queda final foi resultado da vingança de um de seus inimigos. A maior parte da narrativa se passava em Macaé, cidade natal do autor, onde o Dr. Guarani Cardoso se notabilizou como juiz corrupto, perdulário e exibicionista. ${ }^{3}$ Embora fosse também uma ficção sobre pessoas "imorais", o romance de 1895 não se permitia as intimidades físicas do romance de estreia. A história se passava na década de 1880. Havia menções ao crescente movimento abolicionista e alguns clientes do bacharel eram proprietários de escravos. O romance, entretanto, tinha como foco de interesse uma população urbana remediada ou afluente de burocratas, advogados, médicos e funcionários públicos.

Durante o segundo semestre de 1895 a obra foi debatida nos principais jornais e revistas do Rio de Janeiro. Dentre as apreciações críticas, três se destacam pela importância de seus autores e dos periódicos em que foram publicadas: 1 . As resenhas de Valentim Magalhães (1859-1903) no jornal A notícia, nos dias 6 e 10 de agosto de 1895; 2 . A resenha de Artur Azevedo na coluna "Palestra", em $O$ país, no dia 9 de agosto de 1895; e 3. A resenha de José Veríssimo (1857-1916) na Revista Brasileira, tomo IV, outubro-dezembro de 1895. Unidos a algumas notas e comentários esparsos sobre o romance, publicados em outros veículos, os textos revelam como jornalistas e homens de letras compreendiam o naturalismo na década de 1890 , assim como o lugar da obra do estreante Figueiredo Pimentel na estética. Os 
comentários e as resenhas dão voz a opiniões e gostos comuns, mas também revelam discordâncias sobre o que era (e devia ser) um romance naturalista. De todas as críticas, a de Valentim Magalhães era a mais significativa porque deu início, nas páginas do jornal $A$ notícia, a uma polêmica entre o crítico e o autor que ilumina e expande o debate sobre o naturalismo no Brasil.

Para efeito de organização do argumento, apresentaremos o conjunto dos textos a partir de eixos e preocupações comuns, incluindo a réplica de Figueiredo Pimentel, de modo a apreender os termos do debate sobre Um canalha e o naturalismo.

\section{III}

Numa nota de primeira página em $O$ país de 12 de agosto de 1895, o articulista Magriço julgou Um canalha "pouco desenvolvido como tentame psicológico, sem energias de escalpelização" (O país, 12/08/1895, p. 1). Valentim Magalhães e José Veríssimo concordavam: faltava aprofundamento na apresentação do perfil do Dr. Guarani Cardoso; faltava consistência ao "estudo" de Figueiredo Pimentel. Veríssimo julgava tão fraca a caracterização do protagonista - como compreender seu comportamento? -, que não se podia falar em "psicologia do romance" ao se referir a Um canalha (Revista Brasileira, tomo IV, out.-dez. 1895, p.60). Valentim Magalhães ia mais longe e evocava o método experimental de Zola, a seu ver ausente na obra:

Que teve em mira o autor, criando este bandido vulgar, sem nada de atraente nem de simpático? Estudar um caso de "criminoso nato", como o entende Lombroso? Talvez; mas, para isso, devia descrever rigorosamente os estigmas morais desse indivíduo, acompanhando, desde a infância, a formação viciosa, doentia, desse caráter resistente ao meio e à educação e, como faz Zola na Bête Humaine, dando-nos o sentimento e a própria sensação da fatalidade do crime nesse organismo, em aparência perfeito. Nada disso fez, porém, o $\mathrm{Sr}$. Figueiredo Pimentel (A notícia, 06/08/1895, p. 1).

Dentro da concepção de ficção naturalista como "romance científico", a cobrança fazia sentido. A adesão aos princípios e métodos científicos era crucial para o romance naturalista, não por submissão cega à ciência, mas por entender que a literatura não podia se dar ao luxo de dar as costas para as tecnologias e conquistas da civilização industrial. Valentim Magalhães evoca um cientista importante do imaginário naturalista - o italiano Cesare Lombroso (1835-1909), famoso pelos estudos de perfis criminosos. Lembra o método rigoroso de Zola em La Bête Humaine (1890), que acompanhava desde a infância a formação de um organismo fatalmente atraído pelo crime. Ao passo que em Um canalha, nota Veríssimo, o Dr. Guarani Cardoso, de estudante bisonho, econômico e calado em São Paulo, transformava-se sem nenhuma explicação num juiz perdulário, exibido e expansivo em Macaé.

$\mathrm{Na}$ réplica a Valentim Magalhães, no mesmo jornal A notícia, a 9 de agosto de 1895, Figueiredo Pimentel argumentou que o comportamento do bacharel era crível o bastante para qualquer leitor atento: "O distinto escritor não descobriu no protagonista um degenerado, um criminoso nato - cleptomaníaco, se assim posso exprimir - um suicida-maníaco, porque não quis, ou não leu o meu romance, folheando-o apenas mui ligeiramente" (p. 3). O comentário introduzia a palavra "cleptomaníaco" (que não aparecia no romance) como traço definidor do personagem e revela que, para o autor, a capacidade para o crime do Dr. Guarani era uma herança biológica, anterior e superior ao meio em que nasceu e viveu. Adolfo Caminha (18671897) usou o mesmo argumento para explicar o desejo homoafetivo do marinheiro negro Amaro, o protagonista de Bom-Crioulo, publicado naquele mesmo ano no Rio de Janeiro (MENDES, 2000). Como o maníaco Dr. Guarani Cardoso, Amaro - que poderíamos chamar, cientes do anacronismo, de um homem gay - nascera assim: ele era um "degenerado nato" (CAMINHA, 1896, p. 41). Apesar da importância do meio para a ficção naturalista, havia impulsos naturais que the resistiam e sobreviviam.

Para Figueiredo Pimentel, o Dr. Guarani Cardoso era um "cleptomaníaco" no sentido de que roubava compulsivamente, como o conto de réis que lesou de um amigo nos tempos da faculdade, assim como quantias recebidas por clientes em causas advogadas por ele, depois que se formou. Às vezes o bacharel entrava numa espécie de transe, durante os quais perdia o controle de suas ações e agia como um autômato, gastando dinheiro a rodo, metido com agiotas, confabulando grandes crimes e assassinatos, embora fosse, no fundo, um covarde. Desde os tempos de estudante, considerava o suicídio como forma de resolução de suas angústias e problemas financeiros. A cada nova crise, suscitada pela revelação iminente de suas canalhices, ele considerava suicidarse, sempre contando aos amigos e à esposa sua decisão. Quando a revelação por fim acontece e o Dr. Guarani Cardoso vai preso, depois de acumular uma dívida de quarenta contos de réis (uma pequena fortuna) e muitos inimigos, o suicídio - considerado um ato covarde - foi a saída escolhida pelo "canalha".

O debate continuou. Na tréplica, no dia seguinte, Valentim Magalhães insistia na cobrança de rigor na caracterização dos personagens, argumentando que essas fabulações não bastavam para tornar críveis a cleptomania ou a mania de suicídio do protagonista. O crítico explica que tinha em mente a técnica narrativa 
de Gustave Flaubert (1821-1880), que ele considerava o pai da "escola naturalista, ou naturista, na expressão de Goncourt, e que Zola refinou, exagerando" (p. 1). Magalhães evocava uma tradição de ficção naturalista que emanava de Flaubert, e não de Zola, raramente reconhecida pela historiografia (BAGULEY, 1990). Como ele, alguns intelectuais do período julgavam que o naturalismo de Zola era uma forma de "exagero" de um método naturalista "flaubertiano" original, que tinha nos irmãos Goncourt seus herdeiros legítimos.

O crítico conhecia o livro Lettres de Gustave Flaubert a George Sand (1884), de cujo prefácio, assinado por Guy de Maupassant (1850-1893), ele retira uma citação para ilustrar de que naturalismo estava falando quando cobrava mais rigor ao autor de Um canalha:

Seu processo de trabalho [de Flaubert] era mais de penetração que de observação. Em lugar de exibir a psicologia dos personagens, em dissertações explicativas, ele fazia simplesmente aparecer pelos seus atos. $\mathrm{O}$ interior era assim revelado pelo exterior, sem nenhuma argumentação psicológica. Primeiro, imaginava os tipos; e, procedendo por dedução, fazia esses indivíduos praticar as ações características que eles deviam fatalmente praticar, com uma lógica absoluta, de acordo com os seus temperamentos (A noticia, 10/08/1895, p. 1).

Tratava-se de fazer valer o ponto de vista científico sem introduzir "argumentação psicológica" ou "dissertações explicativas" na ficção - como fez, por exemplo, Júlio Ribeiro (1845-1890) em A carne (1888) -, mas pelo desencadear lógico do enredo e do comportamento dos personagens. Assim se cumpria o objetivo do naturalismo de realizar "estudos de temperamentos". Ao romance naturalista Um canalha, faltava, portanto, segundo os críticos, substância e amadurecimento.

Consequentemente, faltava interesse ao personagem central, concordavam Valentim Magalhães e Artur Azevedo. Magalhães esperava encontrar um canalha "interessante, original, extraordinário", mas deparou-se com "um canalha banal, vulgar, sem imaginação, sem inventiva, sem audácia nem cinismo fora do comum" ( $A$ notícia, 06/08/1895, p. 1). Na tréplica, ele explica que era possível transformar um canalha vulgar num "tipo literariamente curioso", e dá como exemplo a protagonista de La fille Elisa (1877), de Edmond de Goncourt (18221896), que era "uma fille qualquer; entretanto, como [era] interessante!" (A notícia, 10/08/1895, p. 1). Para Artur Azevedo, na mesma linha, o protagonista do romance era "um canalha vulgar, vulgaríssimo, que não desperta[va] o mínimo interesse, nem deve [devia] ter as honras de uma análise psicológica" (O país, 09/08/1895, p. 1). Talvez o Dr. Guarani Cardoso servisse como "personagem acessório", escreve Artur, mas como "figura principal [era] muito deficiente".

A questão da banalidade colocava um problema sério para os escritores naturalistas. Num mundo que perdeu contato com a transcendência e com o sagrado, a banalidade do cotidiano (e dos sujeitos) transformava-se na única realidade que existia, adquirindo, por isso, valor por si mesma. Mas como escrever histórias sobre pessoas banais - sobre "les hommes des choses médiocres" (BAGULEY, 1990, p. 132) - sem que a banalidade desse o tom da narrativa, tornando a leitura enfadonha? No romance naturalista esquecido Lar, de Pardal Mallet (1864-1894), publicado no Rio de Janeiro em 1888, o narrador relata os dezoito anos de vida de Sinhá, do nascimento ao casamento, tão banais e rotineiros que a primeira menstruação da protagonista era um dos eventos mais importantes da narrativa (MENDES \& VIEIRA, 2012). Não seria natural esperar que uma ficção sobre sujeitos banais fosse ela mesma banal e desinteressante? Na réplica a Valentim Magalhães, Figueiredo Pimentel reconhece a vulgaridade de seu protagonista, sobre quem, na sua opinião, havia poucas coisas interessantes a dizer. Por isso o romance se chamava "um canalha" - o Dr. Guarani Cardoso não passava de mais um entre tantos outros canalhas iguais a ele, banais e fáceis de encontrar na vida em sociedade.

Apesar de reconhecer uma tradição de ficção naturalista ligada a Flaubert e aos irmãos Goncourt, que subscrevia ao que David Baguley chama de "ortodoxia da banalidade" (1990, p. 124), Valentim Magalhães não abria mão da noção arraigada, com raízes na tradição da epopeia clássica, de que o romance era o lugar do extraordinário, do interessante ou do "fora do comum". Por isso ele pedia a Figueiredo Pimentel que tornasse interessante a banalidade de seu herói. Para figurar num romance, até as prostitutas e os canalhas precisavam mostrar que eram "fora do comum", nem que fosse pela audácia ou pelo cinismo. Artur Azevedo pensava da mesma forma. Para o "papá literário", faltava "invenção" no perfil do personagem principal (O país, 09/08/1895, p. 1). Artur era perspicaz quando dizia que o bacharel parecia um "personagem acessório" (e não o principal), mas ao mesmo tempo esquecia que o romance naturalista queria justamente dar status de protagonista a sujeitos periféricos, "acessórios" ou subalternos (BAGULEY, 1990; BUENO, 1992). Não tinha sido outro o objetivo de seu irmão Aluísio ao colocar uma lavadeira - a mulata Rita Baiana - no centro de $O$ cortiço (1890).

O problema de romances naturalistas esquecidos como Um canalha, de Figueiredo Pimentel, e Lar, de Pardal Mallet, era que eles rejeitavam a expansividade épica associada ao romance como gênero. Pelas páginas de $O$ país, o articulista Magriço tentou explicar o dilema 
posto pela história do Dr. Guarani Cardoso: “A sucessão dos episódios tem a monotonia de um diário, o que é insuportável nas composições deste gênero, muito embora a vida seja isso mesmo - uma sucessão de dias" (O país, 12/08/1895, p. 1). Não se podia contar "com imaginação" histórias sobre sujeitos "sem imaginação", mesmo sob o risco de tornar a leitura "insuportável". Tais romances naturalistas eram "epopeias da impotência humana”, na expressão de Pardal Mallet (2008, p. 236), formas de travestimento do épico e do romance como gênero reservado ao relato dos grandes feitos de homens extraordinários (BAGULEY, 1990), ou ao menos "interessantes".

Desse ponto de vista, era possível rebater a acusação de inverossimilhança lançada a Um canalha, porque não havia nada mais verdadeiro do que uma história banal sobre pessoas banais. O articulista da coluna "Sobre a mesa", do jornal A notícia de 28 de agosto de 1895 , usou esse raciocínio para defender e explicar o romance de Figueiredo Pimentel, ainda que para esse fim fosse necessário abrir mão do interesse da leitura e, talvez, do reconhecimento do público:

\begin{abstract}
Diletante e homens de letras com quem temos conversado sobre a última produção literária do autor do Suicida, mostram-se surpresos por não encontrarem em Um canalha mais do que a relatação de casos possíveis, acrescentando alguns, e por isso censurando o autor, que a principal figura do romance limita-se a uma individualidade de canalha comum, de viveur banal, desses que diariamente acotovelamos nos pontos mais frequentados da vida agitada. Queremos crer que, em vez de prestar-se a um termo de censura, essa qualidade tão criticada do livro torna-se o inverso, isto é, um atestado do seu valor, como trabalho reprodutivo da vida comum, obrigado à máxima verossimilhança, que foi justamente o que o autor quis fazer. O que se dá, constituindo, parece-nos, a causa desse mal entender é que o livro de Figueiredo Pimentel não desperta pela leitura e como leitura, o interesse, nem provoca o aplauso, que, no entanto, pela sua verdade de observação, desperta e provoca. Isso sim (A notícia, 28/08/1895, p. 2).
\end{abstract}

No caso de Um canalha, o risco de ser ignorado pelo público era atenuado pela fama pregressa de Figueiredo Pimentel como autor de $O$ aborto, cujo sucesso de vendas resultava da percepção de que o romance era um produto erótico. Os anúncios do editor Pedro Quaresma colocavam rotineiramente $O$ aborto na categoria de "romance para homens" (EL FAR, 2004), muitas vezes ao lado de ficções assumidamente pornográficas, como os contos de Rabelais, pseudônimo do escritor português Joaquim Alfredo Gallis (1859-1910) - autor, com o próprio nome, de uma série de romances naturalistas do subgênero científico, tais como A taverna (1903), com um título (e com a temática do alcoolismo) claramente inspirados em L'Assommoir (1877), de Zola. O próprio Figueiredo Pimentel declarou no prefácio de $O$ aborto que pouco se importava se fosse "pechado de pornográfico, imoral, bandalho" (1893, p.2), já que outros escritores naturalistas contemporâneos, como Zola, Eça de Queirós (1845-1900), Aluísio Azevedo e Pardal Mallet, haviam sido assim julgados antes dele.

A expectativa de encontrar pornografia em Um canalha foi assumida tanto por Valentim Magalhães quanto por Artur Azevedo. Magalhães confessa que esperava "corar frequentes vezes lendo Um canalha, atento a fama adquirida pelo autor com $O$ aborto". Ele listava a falta de "cenas picantes" como uma das "decepções" do romance (A notícia, 06/08/1895, p. 1). Na réplica, Figueiredo Pimentel devolveu: se o público pensava como o crítico e queria "outra coisa no gênero de $O$ aborto, [haviam] de ser servidos, com a graça de Deus" (A notícia, 09/08/1895, p. 3). Valentim Magalhães entendeu a ironia e se apressou em esclarecer que não apreciava literatura de escândalo: "Não quero absolutamente que o Sr. Pimentel tenha outro Aborto e nem de leve insinuei o desejo desse infortúnio, e faço votos para que a sua ameaça não se realize" ( $A$ notícia, $10 / 08 / 1895$, p. 1), escreveu, sugerindo que o romance era ele mesmo uma obra abortada. De qualquer modo, para ele Um canalha era "mais casto" e "velado" do que $O$ aborto (A notícia, 06/08/1895, p. 1). O articulista de "Sobre a mesa" concordava. Se o aparecimento de $O$ aborto havia criado ao redor do nome de Figueiredo Pimentel "um cordão vigilante de sanidade moral pelos pais cautelosos, em proveito dos filhos", em "Um canalha pode [podiam] pousar todos os olhares, mesmos os pudicos olhares de uma educanda de colégio religioso - se é que sejam estes os mais pudicos" (A noticia, 18/08/1895, p. 2).

Para expressar sua surpresa diante das diferenças entre os dois romances, Artur Azevedo comparou-os a duas obras populares da época. A seu ver, Um canalha estava para $O$ aborto assim "como o Simão de Nantua [estava] para os Serões do convento" (O país, 09/08/1895, p.1). Enquanto a História de Simão de Nantua era um compêndio de textos usados na escola oitocentista com o intuito de condenar os vícios e ensinar a moral e a virtude às crianças (NUNES, 2011), Os serões do convento era um "clássico" da literatura pornográfica do século XIX (EL FAR, 2004, p. 15). A comparação era um exagero, mas deixava claro que até para os homens de letras era difícil separar a ficção naturalista da pornografia. Numa nota favorável ao aparecimento de Um canalha, os redatores da revista carioca $A$ cigarra, liderados por Olavo Bilac (1865-1918), trilhavam o mesmo terreno movediço. Ao mesmo tempo em que exaltavam as qualidades do 
romance como "estudo de temperamento" (associado ao cientificismo), chamavam a atenção para o "sabor picante de fruto proibido" da história, que era uma garantia de boas vendas (A cigarra, n. 14, 08/08/1895, p.3). Uma bela charge de Julião Machado acompanhava a nota.

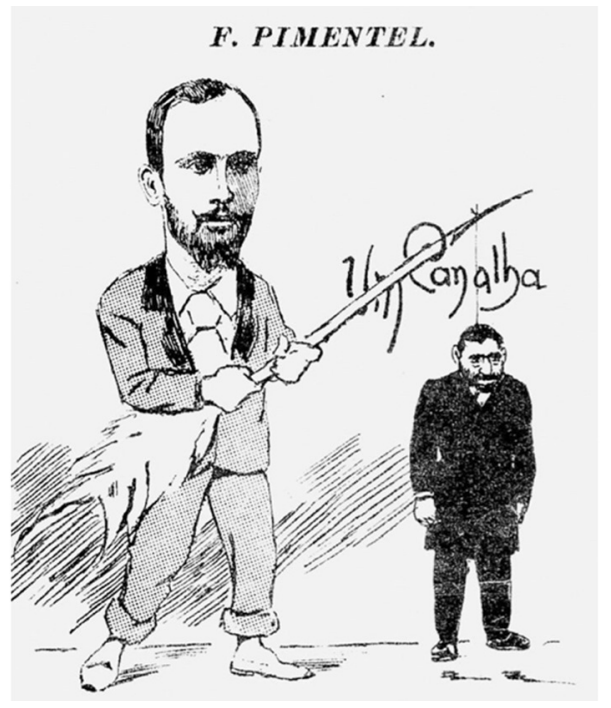

Fig. 3. Figueiredo Pimentel e seu Um canalha em charge de Julião Machado: Dr. Guarani Cardoso enforcado na pena do escritor.

Fonte: Revista A cigarra n. 14, Rio de Janeiro, 08/08/1895, p. 3.

De fato, o Dr. Guarani Cardoso estava longe de ser um Simão de Nantua, e o próprio Artur Azevedo reconhecia que Um canalha não era, afinal, leitura recomendável “às donzelas mais pudibundas" (O país, 09/08/1895, p.1). O romance apresentava uma galeria tão variada de personagens "baixos", que Valentim Magalhães chegou a sugerir a mudança do título de Um canalha para "Uma penca de canalhas" (A notícia, 06/08/1895, p.1). Entre as canalhices do protagonista, talvez a mais chocante fosse pedir à própria mulher que se oferecesse ao barão de Lamego, um capitalista de Macaé, em troca de um empréstimo de vinte contos de réis para saldar dívidas. Nem o ganancioso barão, um idoso mulherengo que se maquiava, de "físico desgracioso e repelente" (PIMENTEL, 1895, p.92), pôde crer que o Dr. Guarani Cardoso fosse capaz de tamanha perfídia. Isabelinha, a esposa, ficou estupefata, mas sua maior preocupação era que o marido estivesse desconfiado de seus amores com o jovem médico Carlos Soares. Antes dele, Isabelinha tinha sido amante do maestro Renani, um artista italiano que se estabelecera em Macaé, e do Afonsinho Sampaio, seu amigo de infância. Com vocabulário naturalista, Artur Azevedo julgou que a esposa do Dr. Guarani Cardoso tinha "nas veias o mau sangue de madame Bovary" (O país, 09/08/1895, p. 1). Para Valentim Magalhães,
Isabelinha era uma "marafona" (A notícia, 06/08/1895, p. 1) - um julgamento comumente estendido a todas as mulheres dos romances naturalistas que faziam sexo fora do casamento.

Como em $O$ aborto, havia em Um canalha poucos personagens admiráveis. Uma exceção era o funcionário público Cândido Ferraz, como notou Valentim Magalhães, o único amigo do Dr. Guarani Cardoso, que o salvou mais de uma vez da falência e do opróbrio. Quando, nas rodas da fortuna, foi a vez de Cândido Ferraz pedir-lhe que adiasse uma cobrança, o bacharel, insensível, não hesitou em privá-lo de todos os bens, incluindo a casa em que morava com a família em Niterói. De resto, era a vida das aparências, interessada em saber quem morava na melhor rua, quem era a moça mais bonita de Macaé, quem dava as melhores festas, e quem era amante de quem. A intriga era onipresente. Sobre a cidade de Campos - onde o Dr. Guarani Cardoso passou alguns anos antes de terminar seus dias em Niterói - escreveu em carta Cândido Ferraz:

\begin{abstract}
A bisbilhotice reina aqui como em parte alguma, e chovem intrigas e mexericos, transmitidos pela boca dos criados. Tasquinha-se enormemente a vida alheia: todo o mundo sabe o que se passa em casa do vizinho, o que ele bebe, o que ele come, o que ele fala. A carta anônima e os pasquins, metidos à noite, por debaixo das portas, além dos letreiros e dizeres injuriosos, escritos nas paredes a carvão, a lápis, a tinta, a giz, e até com... excremento humano (!!!) são armas favoritas, comumente usadas (PIMENTEL, 1895, p. 127).
\end{abstract}

Talvez o comentário não chocasse as "donzelas pudibundas" de Artur Azevedo, mas causou a fúria de campistas. Na réplica a Valentim Magalhães, Figueiredo Pimentel conta que vinha recebendo cartas de "uns mineiros indignados e patriotas campistas", por ter feito o canalha nascer em Minas e morar em Campos. Houve até ameaças anônimas em repúdio à publicação de Um canalha, sugerindo que o romance foi vendido e lido. Na devolução, Figueiredo Pimentel diz que ele foi especialmente mal recebido pelos advogados: “...e a anônimos que me ameaçam, [garanto] que não talhei para eles a carapuça. Parece que há muito Guarani por este mundo de Cristo!" (A notícia, 09/08/1895, p. 3).

Por fim, havia a questão da linguagem "pouco literária" do autor - acusação feita tanto a $O$ aborto quanto a Um canalha. Para Magriço, o romance de 1895 fora escrito "sem escrúpulo de forma" (O país, 12/08/1895, p.1). Já o articulista de "Sobre a mesa", em A notícia, detectou em Um canalha descuidos de redação e "frieza na escrita" - "o assunto exigia ser tratado a frio, é verdade, mas o trabalho podia ser mais comunicativo pela frase" $(A$ noticia, 28/08/1895, p. 2). José Veríssimo compartilhava da mesma opinião: 
Do estilo e da língua do Sr. Figueiredo Pimentel, direi apenas que me parece não ter ele se preocupado nem de um nem da outra. Se o tivesse feito estou certo que não escreveria frases destas: 'estrangularlhe a garganta' (p. 43), 'examiná-los em conhecedor' (p. 47), 'passava o dia às moscas' (p. 62), e teria evitado a repetição de explicativas desnecessárias: 'calado, falando pouco", "pobre, sem fortuna' (p. 152), 'era estéril, sem nunca ter concebido' (p. 145), e um repetido emprego do verbo 'falar' no sentido de dizer, conforme o provincialismo mineiro e paulista, tão impróprio e deselegante e outros quejandos senões (Revista Brasileira, tomo IV, out.-dez. 1895, p. 60-61).

Reunidas, as críticas ao estilo se baseavam no pressuposto de que para ser chamada de "romance", uma narrativa ficcional precisava ser elegante e bem-feita, com "escrúpulo de forma" - o trabalho de tornar a frase "mais comunicativa", embora sem exageros e repetições. Algumas variações linguísticas regionais eram malvistas. Quando Artur Azevedo lamentou que os fios narrativos da primeira parte de Um canalha ficavam sem resolução - "os estudantes desaparecem no quarto capítulo e nunca mais aparecem" -, ele partia da mesma concepção orgânica de obra, cujas partes interagiam para criar um todo harmônico. Ao final da resenha, o escritor veterano aconselhava o autor a "não desanimar e seguir em frente" (O país, 09/08/1895, p. 1), deixando claro que o romance de 1895 ainda não chegara lá.

Por trás das críticas ao estilo de Figueiredo Pimentel havia um conflito entre dois regimes textuais - o literário e o jornalístico -, que era crucial para entender a literatura do século XIX (THÉRENTY, 2007). Tanto o autor de Um canalha quanto seus críticos tinham forte presença nos jornais. Alguns, como Olavo Bilac e Artur Azevedo, eram as principais atrações dos periódicos da capital (e das províncias). Os escritores viviam uma condição peculiar ao século XIX: a "coincidência essencial" entre dois sistemas profissionais, que fazia com que as mesmas pessoas circulassem nos campos jornalístico e literário (THÉRENTY, 2007, p. 18). A questão era que muitos escritores importantes não viam isso com bons olhos. Escritores como José Veríssimo (e muitos outros) consideravam os gêneros jornalísticos formas inferiores de escrita, e o trabalho nos jornais, um mal necessário. Havia um esforço dos homens de letras para impedir que a literatura fosse "contaminada" pelos gêneros jornalísticos.

Poder-se-ia compreender as críticas ao estilo de Figueiredo Pimentel como uma resistência dos escritores dominantes a essa "contaminação". José Veríssimo apontou o vínculo de Um canalha com a literatura de jornal:
Há neste romance uma curiosa mistura de aptidão para o gênero que os franceses chamam roman feuilleton e da preocupação evidente em fazer psicologia segundo a maneira naturalista. $\mathrm{O}$ início do romance, a descoberta do roubo praticado por Manuel Antônio, o "canalha" que dá nome ao livro, e o final, a sua prisão, a vingança de Lúcio Ferraz e o suicídio, de Manuel Antônio, transformado então em Dr. Guarani, são puro Gaboriau, Montepin ou Richebourg, como à mesma escola pertencem outras cenas desse livro, em que se sente uma imaginação viva, excitada, embora sem verdadeira originalidade (Revista Brasileira, tomo IV, out.-dez. 1895, p. 60).

O crítico chama a atenção para a presença, em Um canalha, além da análise psicológica proposta pela estética naturalista, de uma série de temas e estratégias tipicamente folhetinescas: o roubo, a troca de identidades, a vingança e finalmente o suicídio. Veríssimo complementa que a única qualidade "desta casta de romances" é saber interessar o leitor, deixando claro que a seus olhos essas características enfraqueciam a obra, situando-a na classe malvista dos textos que o crítico francês Sainte-Beuve (1839) chamou de literatura industrial.

O romance-folhetim foi o produto mais notório do casamento da literatura com a imprensa no século XIX (MEYER, 1998). Era uma narrativa que gravitava "entre a ficção e a informação" (THÉRENTY, 2007, p. 127). Ele demandava um novo regime de escrita: a escrita com prazo, feita nas redações de jornais, destinada a informar, entreter e fidelizar leitores. $\mathrm{O}$ novo regime entrava em conflito com a concepção romântica dominante do escritor como artista autônomo que criava de forma espontânea e desinteressada (ABREU, 2003). Escrever folhetins podia ser visto como uma forma de rebaixamento para o escritor. E esse julgamento podia ser estendido aos outros gêneros jornalísticos, como a crônica e o fait divers.

Ao contrário de José Veríssimo e de Artur Azevedo (ou mesmo de Aluísio Azevedo), Figueiredo Pimentel não tinha uma carreira de escritor antes de ingressar na imprensa. Desde $O$ aborto, que foi publicado em folhetins, sua prosa era impregnada pelas técnicas e pelo linguajar jornalístico. A "frieza" do estilo, a linguagem "pouco literária", o linguajar popular e regional, os temas escandalosos - aborto, suicídio, roubos, traições - davam aos romances o tom objetivo (e por vezes lacônico) de uma longa reportagem (ou crônica) criminal. O dado de que as histórias de Figueiredo Pimentel seriam baseadas em fatos reais confirma o estatuto ambíguo das narrativas, que eram ao mesmo tempo notícia e ficção, como os folhetins, mas também, como os romances naturalistas, baseadas na observação direta da vida em sociedade. 


\section{IV}

O estudo do romance Um canalha nos convida a expandir nossa concepção de romance naturalista para além do "romance científico" ou "romance experimental", ligado a Zola. A ciência era fundamental para uma visão naturalista de mundo, mas o chamado "romance científico" era apenas um subgênero de uma variedade de apropriações e sentidos possíveis que a palavra "naturalismo" podia acomodar no segundo oitocentos. Havia "cientificismo" nas obras de Figueiredo Pimentel, mesmo que Um canalha não atendesse às exigências de um "romance experimental", como quis Valentim Magalhães. O romance era científico no sentido de que fazia uma narrativa "fria" (que evitava julgar) da trajetória de um tipo facilmente reconhecível na vida em sociedade. Ele era, a seu modo, um "estudo de temperamento".

Outro sentido que a palavra "naturalismo" podia adquirir era o de literatura pornográfica. Não só os leitores comuns e os editores associavam a ficção naturalista à pornografia, mas também os homens de letras tinham dificuldade de separar uma da outra. Não importava que os escritores naturalistas dissessem que seus livros não tinham esse fim. $\mathrm{O}$ fato é que as obras eram anunciadas, vendidas e lidas como histórias sobre sexo. As excelentes vendas de $O$ aborto resultavam dessa percepção. Tal era a fama de autor pornográfico do Figueiredo Pimentel escritor naturalista, que Valentim Magalhães confessou sua decepção com a falta de "cenas picantes" em Um canalha. Mesmo assim, como assinalou a revista A cigarra, as traições e as baixezas dos personagens do romance davam-lhe um "sabor picante de fruto proibido", que era garantia de boas vendas.

Por fim, havia uma acepção de naturalismo como estética da banalidade, a partir de Flaubert, que a historiografia pouco explorou. David Baguley chama essa vertente pouco conhecida de "naturalismo da desilusão" (BAGULEY, 1990). Ligado a uma concepção crepuscular do moderno, o naturalismo desiludido rejeitava as raízes do romance no épico, buscando, ao contrário, retratar o banal, o anti-heroico e o que "não acontecia" na vida dos personagens. A banalidade das situações, dos sujeitos e dos espaços sociais, assim como o fracasso dos protagonistas, era uma marca tanto de $O$ aborto quanto de Um canalha. O banal era por definição despido do "interesse" que os críticos julgavam essencial para que uma história merecesse ser contada e lida. Daí a impressão de Magriço, do jornal $O$ país, de que se lia Um canalha como quem folheava um "diário" - monótono, banal, breves registros comentados, em linguagem "fria", sobre acontecimentos nada grandiosos. Entretanto, como notou o articulista da coluna "Sobre a mesa", do jornal A notícia, o romance, na sua própria incapacidade de despertar interesse e provocar aplauso, era o mais verossímil "trabalho reprodutivo da vida comum".

\section{Referências}

ABREU, Márcia. Letras, Belas Letras, Boas Letras. In: BOLOGNINI, Carmen Zink (org.). História da literatura: o discurso fundador. Campinas: Mercado de Letras, 2003, p. 11-69.

BAGULEY, David. Naturalist fiction. The entropic vision. Cambridge: Cambridge University Press, 1990.

BUENO, Eva Paulino. Brazilian naturalism and the politics of origin, MLN, Baltimore, v. 107, n. 2, p. 363-395, 1992.

CAMINHA, Adolfo. Um livro condenado. A Nova Revista, Rio de Janeiro, n. 2, p. 40-42, 1896.

CATHARINA, Pedro Paulo Garcia Ferreira. De "O artigo 200" a "O aborto": trajetória de um romance naturalista. Letras, Santa Maria, Universidade Federal de Santa Maria, v. 23, n. 47, p. 37-58, jul.-dez. 2013.

EL FAR, Alessandra. Páginas de sensação. Literatura popular e pornográfica no Rio de Janeiro (1870-1924). São Paulo: Cia. das Letras, 2004.

HALLEWELL, Laurence. O livro no Brasil (sua história). São Paulo: EDUSP, 1985.

LEÃO, Andréa Borges. O Brasil em imaginação: livros, impressos e leituras infantis (1890-1915). Fortaleza: UFC, 2012.

MALLET, João Carlos de Medeiros Pardal. Hóspede; Lar. Rio de Janeiro: Academia Brasileira de Letras, 2008.

MENDES, Leonardo; VIEIRA, Renata Ferreira. Epopeia da impotência humana: naturalismo, desilusão e banalidade no romance brasileiro do final do século XIX. Revista E-scrita, n. 3, p. 139-152, set.-dez. 2012.

MENDES, Leonardo. O retrato do imperador: negociação, sexualidade e romance naturalista no Brasil. Porto Alegre: EDIPUCRS, 2000. (Coleção Memória das Letras, 7).

MEYER, Marlyse. Folhetim: uma história. São Paulo: Cia das Letras, 1996.

NEEDEL, Jeffrey. Belle Époque Tropical. Sociedade e cultura de elite no Rio de Janeiro na virada do século. São Paulo: Cia das Letras, 1993.

NUNES, Francivaldo Alves. Leitura e escrita nas aulas de ensino mútuo no Pará oitocentista, Revista Litteris, n. 7, p. 1-12, mar. 2011.

PIMENTEL, Alberto Figueiredo. $O$ aborto. Rio de Janeiro: Livraria do Povo: Quaresma \& Comp., 1893.

PIMENTEL, Alberto Figueiredo. Um canalha. Rio de Janeiro: Livraria Laemmert, 1895.

SAINTE-BEUVE, Charles Augustin. De la littérature industrielle, Revue des Deux Mondes, $1^{\text {er }}$ sept., p. 675-691, 1839.

THÉRENTY, Marie-Ève. La littérature au quotidien. Poétiques journalistiques au XIXe siècle. Paris: Seuil, 2007.

\section{Jornais e revistas consultados}

Hemeroteca Digital Brasileira/FBN: <http://hemerotecadigital. bn.br/>.

Gazeta de Noticias, Gazeta da Tarde, Província do Rio, O país, A notícia, O álbum, A cigarra, Revista Brasileira.

Recebido: 26 de abril 2014 Aprovado: 10 de setembro 2014 Contato: leonardomendes@utexas.edu rfv_30@yahoo.com.br 